\title{
Prospects of strawberry cultivation in Haryana State, India
}

\section{Gurpreet Singh Bachhal*}

Department Of Extension Education, Chaudhary Charan Singh Haryana Agricultural University, Hisar (Haryana), India

\section{Pardeep Kumar Chahal}

Department Of Extension Education, Chaudhary Charan Singh Haryana Agricultural University, Hisar (Haryana), India

\section{Pawan Kumar}

Department Of Extension Education, Chaudhary Charan Singh Haryana Agricultural University, Hisar (Haryana), India

\section{*Corresponding author. E-mail: preet.bachhal11@gmail.com}

\begin{abstract}
The study on the prospects of strawberry cultivation by the strawberry growers indicated that overall prospects of strawberry cultivation were medium to high since 78 percent belonged to these categories. The study was conducted in Bhiwani and Hisar districts. Prospects were categorized into two categories i.e. production related prospects and general prospect of strawberry cultivation. Majority of farmers agreed that demand is increasing day by day (weighted mean score 2.78) which is an indication of innovativeness (weighted mean score 2.76), status in village (weighted mean score 2.68). The purchasing power of people increased (weighted mean score 2.64) The better economic returns in comparison to other fruit crops (weighted mean score 2.62) and high nutritious value of fruit (weighted mean scores 2.62) were osberved. In case Govt. provides facilities, it would take the persons to go for strawberry cultivation (weighted mean score 2.58). The food habit of people changed (weighted mean score 2.54). The high price (weighted mean score 2.52) was suitable for agro-processing (weighted mean score 2.5), whereas better export facilities available (weighted mean score 1.88), farmer friendly being easy to produce (weighted mean score 1.56), better market facilities available at present (weighted mean score 1.52) and better technical support available(weighted mean score 1.44) were not upto the desired level of prospects as perceived by strawberry growers.
\end{abstract}

Keywords: Cultivation, Innovativeness, Prospects, Strawberry

\section{INTRODUCTION}

Strawberry, a high-valued fruit, has gained a spectacular hike in the area as well as the production in a developing country like India. According to the National Horticulture Board, the total area under strawberry cultivation in Haryana was about 150 hectares with a production of 2010 MT in the year 2016-17 (Anonymous, 2017). The cultivated strawberry is predominantly used as fresh fruit and enjoyed by millions of people in all climates, including temperate, Mediterranean, sub-tropical, and taiga zones. In India, it is mainly grown in Himachal Pradesh, Jammu \& Kashmir, Uttar Pradesh, Maharashtra, West Bengal, Punjab, Haryana, Rajasthan, Delhi and the Nilgiri hills in India. Maharastra's Panchgani-Mahabaleshwar belt leads the country's strawberry production (Anonymous, 2011-2012).

The fruit is of aggregate type, having seeds (achene) on the surface of red fleshy receptacle (Darnell, 2003). The edible portion of fruit is about

\section{Article Info}

DOI:10.31018/jans.v10i4.1870 Received: August 15, 2018

Revised: September 26, 2018

Accepted: October 10, 2018

\section{How to Cite}

Bachhal, G.S. et al. (2018). Prospects of strawberry cultivation in Haryana State, India. Journal of Applied and Natural Science, 10(4): 1130 -1133 
ice creams and milk shakes. Keeping in view the above facts and importance of fruit crop for country as whole and Haryana state in particular, the study was conducted to find out the prospects of strawberry cultivation technology in Haryana.

\section{MATERIALS AND METHODS}

To collect primary data of farmers' adoption level of strawberry cultivation technology in Haryana, 50 respondents were collected by applying purposive technique. Among fruit growing states of India, Haryana was selected purposively being direct access to investigators and Saharwa village in Haryana emerging as hub of strawberry cultivation. The Hisar and Bhiwani districts were selected purposively due to large number of farmers, Saharwa from Hisar and Chanana village from Bhiwani district were selected purposively. However, Saharwa village was more focused as it is emerging as the hub of strawberry cultivation in north India. Fifty strawberry growers were selected randomly. Hence, a total of 50 farmers constituted the sample of the study.

Data were collected with well structured and pretested interview schedule. The Schedule consisted 19 items like Better economic returns in comparison to other fruit crops, High nutritious value of fruit, high price, suitable for agro-processing, etc. Responses were obtained on 3 point continuum scale as Agree, Undecided and Disagree and scores were given 3, 2 and 1 . After that frequency was multiplied with the score $(3,2$ or 1$)$ and total weighted score was obtained and total weighted score was divided by total respondents (50) for weighted mean score. Data was analysed with weighted mean score, percentage and rank order.

\section{RESULTS AND DISCUSSION}

Overall prospects of strawberry cultivation technology: The results related to overall prospects of strawberry cultivation contained in Table 1 represented that 62 per cent of the respondents perceived medium prospects of strawberry cultivation, whereas 22 per cent of respondents perceived low prospects of strawberry cultivation and 16 per cent respondents perceived high prospects of strawberry cultivation.

Succinctly, $78 \%$ of the respondents had prospects of strawberry cultivation technology from medium to high level. Low level of prospects may be in deprivation of better technical support linked with strawberry. The present study gets support from Kumar (2016) who reported that majority of farmers has medium (57.5\%) prospects level followed

Table 1. Overall level of prospects of strawberry cultivation $(n=50)$.

\begin{tabular}{llll}
\hline S. N. & Prospects level & Frequency & Percentage \\
\hline 1. & Low (32-39) & 11 & 22 \\
2. & Medium (40-47) & 31 & 62 \\
3. & High (48-55) & 8 & 16 \\
\hline
\end{tabular}

by $22.5 \%$ low level and only $20.0 \%$ to high level. In nutshell, $77.5 \%$ of the respondents had prospects of $C$. sinensis cultivation from medium to high level. The study gets support from Negi (2011) who reported that prospects growth of apple production can be increased in Kinnaur district of Himachal Pradesh if modern technology, availability of high quality of seeds, proper management of labour, graders, packing and transport, marketing, better quality of pesticides, insecticides, fertilizers and proper irrigation facilities etc. are provided.

Production related prospects of strawberry cultivation technology: Table 2 elaborates the production-related prospects of strawberry cultivation in which majority of the strawberry growers agreed on better economic returns in comparison to other fruit crops with weighted mean score 2.62 $(87.33 \%)$ occupying the first rank, while 'high price' with weighted mean score 2.52 (84\%) occupied second rank, followed by 'your past experience favouring strawberry cultivation with weighted mean score 2.26 (75.33\%) occupying third rank, 'water saving crop' with weighted mean score $2.18(72.67 \%)$ occupying fourth rank. Whereas 'farmer-friendly being easy to produce' with weighted mean score $1.56(52 \%)$ occupied fifth rank. It was revealed that farmers were ready to adopt strawberry cultivation due to better remuneration.

Better economic returns as compared to other fruit crops and high price were major prospects of strawberry cultivation technology due to high demand and low supply in the area. The study is supported by Rohila et al.(2014) who reported that prospects of direct seeded rice in Haryana state such as better quality of products and better economic return play an important role to motivate and adoption. 'your past experience favours strawberry cultivation' was the medium prospects because seeing the better remuneration favors crop adoption but wilting of crown of strawberry reduces its aspects for adoption causing the farmers replant the runners, might be responsible for its medium level of prospects. 'Water saving crop' due to frequent use of irrigation at small intervals and 'Farmer friendly being easy to produce' fell into low level of prospects being labour intensive crop and high initial investment.

General prospects of strawberry cultivation: Present study in Table 3 elaborates results pertaining to general prospects in which most of the farmers agreed 'demand is increasing day by day' with weighted mean score $2.78(92.67 \%)$ giving first rank, 'indication of innovativeness' with weighted mean score $2.76(92 \%)$ ranked second, 'status in village' with weighted mean score 2.68 $(89.33 \%)$ was ranked third, whereas fourth rank was given to 'purchasing power of people is increasing' with weighted mean score 2.64 (88\%), 
Table 2. Production related prospects of strawberry cultivation $(n=50)$.

\begin{tabular}{|c|c|c|c|c|c|c|c|c|}
\hline \multirow{2}{*}{$\begin{array}{l}\text { S. } \\
\text { N. }\end{array}$} & \multirow[t]{2}{*}{ Statements } & \multicolumn{3}{|c|}{ Prospects level } & \multirow{2}{*}{$\begin{array}{l}\text { Total } \\
\text { Weighted } \\
\text { Score }\end{array}$} & \multirow{2}{*}{$\begin{array}{l}\text { Weighted } \\
\text { mean } \\
\text { score }\end{array}$} & \multirow{2}{*}{$\begin{array}{l}\text { Prospects } \\
(\%)\end{array}$} & \multirow{2}{*}{$\begin{array}{l}\text { Rank } \\
\text { order }\end{array}$} \\
\hline & & $\begin{array}{l}\text { Agree } \\
\text { (3) }\end{array}$ & $\begin{array}{l}\text { Undecided } \\
\text { (2) }\end{array}$ & $\begin{array}{l}\text { Disagree } \\
\text { (1) }\end{array}$ & & & & \\
\hline 1. & $\begin{array}{l}\text { Better economic returns in } \\
\text { comparison to other fruit crops }\end{array}$ & $35(70)$ & $11(22)$ & $4(8)$ & 131 & 2.62 & 87.33 & $\mathrm{~T}$ \\
\hline 2. & $\begin{array}{l}\text { Farmer friendly being easy to } \\
\text { produce }\end{array}$ & $10(20)$ & $8(16)$ & $32(64)$ & 78 & 1.56 & 52.00 & V \\
\hline 3. & High price & $29(58)$ & $18(36)$ & $3(6)$ & 126 & 2.52 & 84.00 & II \\
\hline 4. & Water saving & $21(42)$ & 17(34) & $12(24)$ & 109 & 2.18 & 72.67 & IV \\
\hline 5. & $\begin{array}{l}\text { Your past experience favours } \\
\text { strawberry cultivation }\end{array}$ & 28(56) & $7(14)$ & $15(30)$ & 113 & 2.26 & 75.33 & III \\
\hline
\end{tabular}

Percentage given in parenthesis

Table 3. General prospects of strawberry cultivation $(n=50)$

\begin{tabular}{|c|c|c|c|c|c|c|c|c|}
\hline \multirow{2}{*}{$\begin{array}{l}\text { S. } \\
\text { N. }\end{array}$} & \multirow[t]{2}{*}{ Statements } & \multicolumn{3}{|c|}{ Prospects level } & \multirow{2}{*}{$\begin{array}{l}\text { Total } \\
\text { weighted } \\
\text { score }\end{array}$} & \multirow{2}{*}{$\begin{array}{l}\text { Weighted } \\
\text { mean } \\
\text { Score }\end{array}$} & \multirow{2}{*}{$\begin{array}{l}\text { Prospects } \\
\text { (\%) }\end{array}$} & \multirow{2}{*}{$\begin{array}{l}\text { Rank } \\
\text { order }\end{array}$} \\
\hline & & $\begin{array}{l}\text { Agree } \\
\text { (3) }\end{array}$ & $\begin{array}{l}\text { Undecided } \\
\text { (2) }\end{array}$ & $\begin{array}{l}\text { Disagree } \\
\text { (1) }\end{array}$ & & & & \\
\hline 1. & $\begin{array}{l}\text { Demand is increasing day by } \\
\text { day }\end{array}$ & $42(84)$ & $5(10)$ & $3(6)$ & 139 & 2.78 & 92.67 & $\mathrm{I}$ \\
\hline 2. & $\begin{array}{l}\text { Better technical support is } \\
\text { available }\end{array}$ & $7(14)$ & $8(16)$ & $35(70)$ & 72 & 1.44 & 48.00 & XIV \\
\hline 3. & $\begin{array}{l}\text { Better credit facilities are } \\
\text { available at present }\end{array}$ & $24(48)$ & $11(22)$ & $15(30)$ & 109 & 2.18 & 72.67 & $\mathrm{x}$ \\
\hline 4. & $\begin{array}{l}\text { Food habit of people is chang- } \\
\text { ing }\end{array}$ & $37(74)$ & $3(6)$ & $10(20)$ & 127 & 2.54 & 84.67 & VII \\
\hline 5. & $\begin{array}{l}\text { Better input facilities are avail- } \\
\text { able }\end{array}$ & $19(38)$ & $5(10)$ & $26(52)$ & 93 & 1.86 & 62.00 & XII \\
\hline 6. & Suitable for agro-processing & $30(60)$ & $15(30)$ & $5(10)$ & 125 & 2.50 & 83.33 & VIII \\
\hline 7. & $\begin{array}{l}\text { Better export facilities are } \\
\text { available }\end{array}$ & $8(16)$ & $28(56)$ & $14(28)$ & 94 & 1.88 & 62.67 & XI \\
\hline 8. & $\begin{array}{l}\text { Purchasing power of people is } \\
\text { increasing }\end{array}$ & $35(70)$ & $12(24)$ & $3(6)$ & 132 & 2.64 & 88.00 & IV \\
\hline 9. & $\begin{array}{l}\text { Better market facilities are } \\
\text { available at present }\end{array}$ & $9(18)$ & $8(16)$ & $33(66)$ & 76 & 1.52 & 50.67 & XIII \\
\hline 10. & $\begin{array}{l}\text { Better for only those who are } \\
\text { residing near the city }\end{array}$ & $24(48)$ & $15(30)$ & $11(22)$ & 113 & 2.26 & 75.33 & IX \\
\hline 11. & $\begin{array}{l}\text { In case Govt. provides facility } \\
\text { would you take up strawberry } \\
\text { cultivation? }\end{array}$ & $34(68)$ & $11(22)$ & $5(10)$ & 129 & 2.58 & 86.00 & VI \\
\hline 12. & High nutritious value of fruit & $34(68)$ & $13(26)$ & $3(6)$ & 131 & 2.62 & 85.33 & V \\
\hline 13. & Status in village & $36(72)$ & 12(24) & 2(4) & 134 & 2.68 & 89.33 & III \\
\hline 14. & Indication of innovation & $38(76)$ & $12(24)$ & $0(0)$ & 138 & 2.76 & 92.00 & II \\
\hline
\end{tabular}

Percentage given in parenthesis

while 'high nutritious value of fruit' with weighted mean score 2.62 (87.33\%), 'in case Govt. provides facility would you take up strawberry cultivation?' with weighted mean score 2.58 (86\%), 'food habit of people is changing' with weighted mean score $2.54(84.67 \%)$, 'suitable for agroprocessing' with weighted mean score 2.50 $(75.33 \%)$. 'Better for only those who are residing near the city' with weighted mean score 2.26 , 'better credit facilities are available at present' with weighted mean score 2.18 (72.67\%) and 'better export facilities are available' with weighted mean score 1.88 (75.33\%) occupied fifth, sixth, seventh, eighth, ninth, tenth and eleventh rank, respectively. While 'better input facilities are available' with weighted mean score $1.86(62 \%)$, 'Better market facilities are available at present' with weighted mean score $1.52(50.67 \%)$ and 'Better technical support is available' with weighted mean score $1.44(48 \%)$ occupied twelth rank, thirteenth rank and fourteenth rank, respectively.
The present study shows that demand is increasing day by day, indication of innovativeness, status in village, purchasing power of people is increasing, high nutritious value of fruit, in case Govt. provides facility would you take up strawberry cultivation?, food habit of people is changing and suitable for agro-processing were major prospects of strawberry cultivation technology. High nutritous value being rich source of anthocyanin possessing high antioxidant activity (Sun et al., 2002) and having potentially anti-cancer compound known as ellagic acid (Basu et al., 2014), increasing purchasing power of people, indication of innovativeness, status in village and suitable for agro-processing are the various factors for increasing demand of the strawberry. The present study showed that Better for only those who are residing near the city medium level of prospects. Better credit facilities available at present, better export facilities available, better input facilities are available, Better market facilities available at present and Better technical 
support available had low level of prospects as for input materials, growers has to acquire runners from himachal Pradesh in case of marketing growers sell crop to commission agents in delhi who has huge margin in it. Study gets support from kumar et al., (2016) who reported that Credit facilities play an important role in adoption of any technology. If farmers faced financial problem then new technology would not be adopted. Technical support and credit facility is mainly responsible for low level of adoption of technology. Better input facilities such as good quality runners etc., are needed because non availability of micropropagation unit to produce runners, growers are compelled to procure runners without quality assurance from long distance which is highly expensive to farmers. Farmers have to plant runners again due to unsuccessful sprouting of runners which increases cost of production by rupees 50,000 to 90,000 per acre. Thus, Hi-Tech green house and tissue culture laboratory for strawberry should be established to produce the quality runners locally and to make available the runners at cheaper rates.

\section{Conclusion}

The present study concluded that overall prospects of strawberry cultivation perceived by strawberry growers were medium to high. Majority of strawberry growers agreed with Better economic returns in comparison to other fruit crops, High price, Demand is increasing day by day, Purchasing power of people is increasing, Status in village, Indication of innovation, High nutritious value of fruit, Suitable for agro-processing,, In case Government provides facility would you take up strawberry cultivation? as major prospects. 'Your past experience favouring strawberry cultivation' and 'Better for only those who are residing near the city' were agreed at medium level of prospects. Whereas, 'water saving crop' due to frequent use of irrigation at small intervals and 'Farmer friendly being easy to produce' being labour intensive crop and high initial investment, 'better credit facilities are available at present', 'better export facilities are available', 'better input facilities are available', 'better market facilities are available at present' and 'better technical support is available' fell into low level of prospects. Frequent trainings should be organized for the extension functionaries and strawberry growers to keep them updated with current advances in strawberry production technology. In order to reduce marketing problems of the strawberry growers, proper procurement policy should be implemented by government by fixing the minimum support price of the fruit crop. Trained extension functionary must be made available to farmers for timely guidance in response to the problems encountered by them during the strawberry cultivation. Providing export oriented trainings to strawberry growers, installation of small scale local processing industry is necessary as fruit is highly perishable in nature, establishing local outlets by cooperatives or government, facility of transport with cold storage to strawberry growers, availability of package of practices or technical know-how on strawberry production technology to farmers at regional level as to make them aware of scientific practices of strawberry production that would increase yield by reducing cost of production. Self help groups can be formed to buy products from the farmers and sell in appropriate market eliminating the role of commission agents/middlemen, timely visit of concerned specialists in the strawberry fields are the various recommendations for better prospects of strawberry in Haryana state in India particularly.

\section{REFERENCES}

1. Anonymous (2011-12). Statistical Abstracts of Haryana. Economics and Statistical Organization, Planning Department of Haryana, Chandigarh.

2. Anonymous (2017). Horticulutre at glance. Horticulture statistics division. Department of agriculture, Ministry of Agriculture and Farmers Welfare, Government of India.

3. Basu, A., Nguyen, A., Betts, N. M. and Lyons, T. J. (2014). Strawberry as a functional food-an evidence based review. Critical Reviews Food Science Nutrition 54 : 790-806.

4. Darnell, R. (2003). Strawberry growth and development. In : The Strawberry : A Book for Growers and Others, Childers, N. F. (ed.) Horticultural Sciences Department, Institute of Food and Agricultural Sciences, University of Florida, Gainesville, Florida, USA.

5. Galletta and Bringhurst. (1995). Small fruit culture and nutritional value. The AV Publishing West Report, 5th edition, USA : 357.

6. Guo, C., Cao, G., Sofic, E. and Prior, R. L. (1997). High performance liquid chromography coupled with colometric array detection of electromagnetic components in fruits and vegetables. Relationship to oxygen radical absorbance capacity. Journal of Agricultural and Food Chemistry $45: 1787-1796$.

7. Negi, P. P. (2011). A survey of growth prospects of apple production in Kinnaur district of Himachal Pradesh. Directorate of Horticulture, Kinnaur, Himachal Pradesh.

8. Rohila, A.K., Ghanghas, B.S. and Shehrawat, P.S. (2014). Prospects of Direct Seeded Rice Cultivation Technol-ogy in Haryana. Journal of Community Mobilization and Sustainable development. 9(2): 206-209.

9. Sun, J., Chu, Y. F., Wu, X. and Liu, R. H. (2002). Antioxidant and anti-proliferative activities of common fruits. Journal of Agricultural and Food Chemistry 50 : 7449-7454.

10.Kumar, P., Shehrawat, P.S., Rohila, A.K., Ghanghas, B.S and Kumar, A. (2016). Prospects of Citrus sinensis (masumbi) cultivation in Haryana State, India. 8 (2): $782-784$ 